\title{
Arabidopsis DND2, a Second Cyclic Nucleotide-Gated Ion Channel Gene for Which Mutation Causes the "Defense, No Death" Phenotype
}

\author{
Grace I. Jurkowski, ${ }^{1,2}$ Roger K. Smith, Jr., ${ }^{2}$ I-ching Yu, ${ }^{2}$ Jong Hyun Ham, ${ }^{1,2}$ Shashi B. Sharma, ${ }^{3}$ \\ Daniel F. Klessig, ${ }^{3}$ Kevin A. Fengler, ${ }^{2}$ and Andrew F. Bent ${ }^{1,2}$ \\ ${ }^{1}$ Department of Plant Pathology, University of Wisconsin-Madison, Madison, WI 53706, U.S.A.; ${ }^{2}$ Department of Crop \\ Sciences, University of Illinois at Urbana-Champaign, Urbana, IL 61801, U.S.A.; ${ }^{3}$ Boyce Thompson Institute for Plant \\ Research, Ithaca, NY 14853, U.S.A.
}

Submitted 10 October 2003. Accepted 22 December 2003.

\begin{abstract}
A previous mutant screen identified Arabidopsis dndl and dnd2 "defense, no death" mutants, which exhibit loss of hypersensitive response (HR) cell death without loss of genefor-gene resistance. The $d n d 1$ phenotype is caused by mutation of the gene encoding cyclic nucleotide-gated (CNG) ion channel AtCNGC2. This study characterizes $d n d 2$ plants. Even in the presence of high titers of Pseudomonas syringae expressing avrRpt2, most leaf mesophyll cells in the $d n d 2$ mutant exhibited no HR. These plants retained strong RPS2-, RPM1-, or RPS4-mediated restriction of $P$. syringae pathogen growth. Mutant $d n d 2$ plants also exhibited enhanced broad-spectrum resistance against virulent $P$. syringae and constitutively elevated levels of salicylic acid, and pathogenesis-related (PR) gene expression. Unlike the wild type, $d n d 2$ plants responding to virulent and avirulent $P$. syringae exhibited elevated expression of both salicylatedependent $P R-1$ and jasmonate and ethylene-dependent $P D F 1.2$. Introduction of $n a h G^{+}$(salicylate hydroxylase) into the $d n d 2$ background, which removes salicylic acid and causes other defense alterations, eliminated constitutive disease resistance and $P R$ gene expression but only weakly impacted the $\mathrm{HR}^{-}$phenotype. Map-based cloning revealed that $d n d 2$ phenotypes are caused by mutation of a second CNG ion channel gene, AtCNGC4. Hence, loss of either of two functionally nonredundant CNG ion channels can cause
\end{abstract}

Corresponding author: A. Bent; Telephone: +1.608 .265 .3034 ; E-mail: afb@plantpath.wisc.edu

G. I. Jurkowski and R. K. Smith contributed equally to this work.

Current Address for G. I. Jurkowski and A. F. Bent: Department of Plant Pathology, University of Wisconsin-Madison.

Current Address for R. K. Smith, Jr.: The Institute for Genomic Research, Rockville, MD 20850, U.S.A.

Current Address for I. Yu: CDIB-Bioscience Venture Management, San Diego, CA 92122, U.S.A.

Current Address for J. H. Ham: Department of Plant Pathology, Ohio State University, Columbus, $\mathrm{OH} 43210$.

Current Address for S. B. Sharma: S. R. Noble Foundation, Ardmore, OK 73402, U.S.A.

Current Address for K. A. Fengler: DuPont Agricultural Biotechnology, Newark, DE 19714, U.S.A.

* The $\boldsymbol{e}$-Xtra logo stands for "electronic extra" and indicates that Figure 7 appears in color on-line. dnd phenotypes. The $d n d$ mutants provide a unique genetic background for dissection of defense signaling.

Additional keywords: avrRpm1, P. syringae pv. tomato.

Mutations that alter plant defenses have been employed by many researchers to understand the molecular basis of defense signal transduction and plant disease resistance. Arabidopsis has been a valuable species for this type of research, not only for cloning plant genes involved in disease resistance but also for building integrated models that describe defense signal transduction pathways and their interrelationships. A number of excellent reviews of this subject are available (Dangl and Jones 2001; Dong 2001; Glazebrook 2001; McDowell and Dangl 2000; Zhang and Klessig 2001).

Arabidopsis dnd (defense, no death) mutants have been isolated and characterized (Chan et al. 2003; Clough et al. 2000; Govrin and Levine 2000; Jirage et al. 2001; Yu et al. 1998, 2000). The dndl mutant has similarities to other Arabidopsis constitutive defense mutants including $\mathrm{cpr}$, cim, lsd, and acd lines (Bowling et al. 1994; Dietrich et al. 1994; Greenberg and Ausubel 1993; Maleck et al. 2002). These mutants exhibit elevated levels of salicylic acid (SA), constitutive expression of pathogenesis-related (PR) genes, and increased levels of resistance to virulent pathogens (Glazebrook 2001). However, $d n d 1$ plants differ from most "constitutive defense" mutants in that, in addition to the above phenotypes, they produce little or no hypersensitive response (HR) cell death in response to avirulent Pseudomonas syringae (Yu et al. 1998). Despite this loss of the HR, dndl mutants retain strong $R$ gene-mediated disease resistance. DND1 encodes the cyclic nucleotide-gated (CNG) ion channel AtCNGC2 (Clough et al. 2000; Maser et al. 2001). Loss of this ion channel is recessive and causes the dndl mutant phenotypes (Clough et al. 2000). The Arabidopsis agd2, acd6, hrll, and hlml mutants have also been reported to exhibit a reduced HR (Balague et al. 2003; Devadas and Raina 2002; Devadas et al. 2002; Rate and Greenberg 2001; Rate et al. 1999). Arabidopsis $\mathrm{HR}^{-}$mutants are useful tools for the study of defense activation and cell-death pathways.

The HR is a rapid and localized programmed cell death of host cells that occurs at the site of infection of an avirulent pathogen (Heath 2000). Gene-for-gene ( $a v r / R$-mediated) defense activation usually but not always causes HR cell death, and the HR is therefore closely associated with $R$ gene-mediated disease resistance (Beers and McDowell 2001; Heath 
2000; Richberg et al. 1998). Depending on the pathogen, the HR may help limit pathogen growth by promoting plant cell wall reinforcement, by eliminating host functions necessary for pathogen multiplication (e.g., for biotrophic fungi and viruses), by depriving the pathogen of nutrients or by fostering release of antimicrobial enzymes or other antimicrobial metabolites (Dixon 1994; Richael 1999; Richberg et al. 1998). The HR also promotes release of elicitors that activate defense responses in surrounding cells and systemically throughout the plant (Alvarez et al. 1998; Dorey 1997; Heath 2000; Ryals et al. 1997). However, the relative role of the HR remains unclear, as it has been shown in numerous studies that HR cell death is not always required for $a v r / R$-mediated disease resistance (Bendahmane et al. 1999; del Pozo and Lam 1998; Kohm et al. 1993; Yu et al. 1998, 2001). Biochemical and genetic studies have identified SA, reactive oxygen species, and nitric oxide as key regulators of HR induction (Beers and McDowell 2001; Heath 2000; Richberg et al. 1998). There is evidence that HR cell death promotion or inhibition may depend as much on the balance among these compounds and among the proteins that regulate their presence as on their absolute concentration (Delledonne et al. 2001; Klessig et al. 2000). Some genes that are not $R$ genes but which modulate $a v r-R$ gene signal transduction have been identified (Aarts et al. 1998; Muskett et al. 2002; Tornero et al. 2002), but there is ample need for further identification of the genes and physiological conditions that control HR cell death.

In many but not all plant species, salicylic acid plays important roles as an inducer of systemic acquired resistance (SAR), PR gene expression, and other defense-related responses (Delaney 1994; Dong 2001; Gaffney 1993; Ryals et al. 1996). Plants expressing the bacterial gene $n a h G^{+}$, whose salicylate hydroxylase product degrades SA to catechol, do not develop SAR, are delayed in expressing an HR, and show enhanced susceptibility to virulent pathogens and decreased resistance to normally avirulent pathogens (Chivasa and Carr 1998; Delaney 1994; Gaffney 1993; Rao and Davis 1999). We have previously observed that Arabidopsis dndl mutants expressing $n a h G^{+}$lose their elevated resistance to virulent and avirulent pathogens, potentially confirming the role of elevated SA in

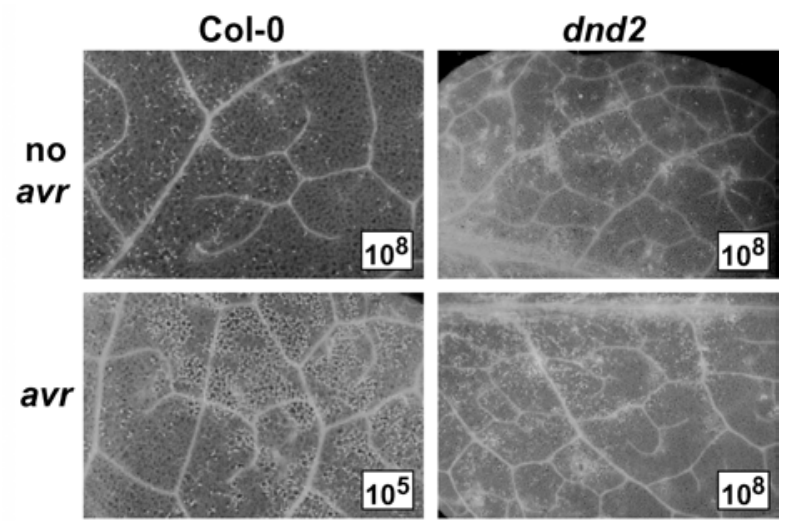

Fig. 1. $d n d 2$ plants are defective in execution of the hypersensitive response (HR) in response to avirulent $P$. syringae. Leaves sampled $24 \mathrm{~h}$ after inoculation. Leaf cells that have undergone the HR are visible as autofluorescent flecks (leaf veins are constitutively autofluorescent). Note that the Col-0/avr leaf in this figure (the $\mathrm{HR}^{+}$positive control) was inoculated with $5 \times 10^{5} \mathrm{CFU} / \mathrm{ml}$, a 400 -fold lower titer of bacteria than the other three leaves, which were inoculated with $2 \times 10^{8} \mathrm{CFU} / \mathrm{ml}$ of bacteria. $\mathrm{Col} /$ avr inoculated at $2 \times 10^{8} \mathrm{CFU} / \mathrm{ml}$ exhibit confluent autofluorescence and total collapse of leaf tissue $24 \mathrm{~h}$ after inoculation (not shown). no $a v r=$ inoculated with Pseudomonas syringae pv. glycinea R4 pVSP61 (no cloned $a v r$ gene); $a v r=$ inoculated with $P$. syringae pv. glycinea R4 pV288 (expressing avrRpt2). those phenotypes (Clough et al. 2000). However, dndl plants that express $n a h G^{+}$still exhibit some dwarfing and retain the loss-of-HR phenotype, suggesting that SA-independent phenomena also contribute to $d n d l$ phenotypes (Clough et al. 2000). In light of recent studies, results obtained using $n a h G^{+}$ must be interpreted with caution (Heck et al. 2003; vanWees and Glazebrook 2003).

In addition to SA-dependent pathways, SA-independent pathways are also activated in response to various pathogens (Conrath et al. 2002; Dong 1998, 2001; Pieterse and van Loon 1999). At least some of these SA-independent pathways require the signaling molecules jasmonic acid (JA) and ethylene. These signaling pathways had previously been characterized in relation to wounding responses (Hildmann et al. 1992) but now have been associated with some aspects of disease resistance. When activated, these pathways can elicit an induced systemic resistance (ISR) of moderate strength that is effective against a different spectrum of pathogens than SAR (Conrath et al. 2002; Penninckx et al. 1996; Pieterse and van Loon 1999; Ton et al. 2002). The PDF1.2 gene is expressed during ISR but not SAR and serves as a widely used marker for ISR and JA and ethylene-mediated defense signaling (Dong 2001; Penninckx et al. 1996).

The mutant screen that produced the $d n d l$ line also yielded other quantitative loss-of-HR mutants (Yu et al. 2000). Among these was the $d n d 2$ mutant line, which together with the $d n d l$ mutant exhibited the strongest suppression of HR (Yu et al. 2000). In the present study, we used a map-based cloning approach to reveal that DND2 encodes a CNG ion channel, $A t C N G C 4$. As we completed map-based cloning of DND2, Balague and colleagues (2003) reported that the Arabidopsis $h l m 1$ mutant also carries a mutation in AtCNGC4. The present work also reports our molecular and physiological characterization of $d n d 2$ plants.

\section{RESULTS}

\section{Microscopic observation}

\section{demonstrates that $d n d 2$ plants are $\mathrm{HR}^{-}$.}

The plant line originally called Y3 but subsequently referred to as $d n d 2$ was isolated in a screen for Arabidopsis mutants that exhibit an altered HR following inoculation with $P$. syringae that express avrRpt2 (Yu et al. 2000). This line bore superficial resemblance to the Arabidopsis dndl mutant line identified in the same screen. Genetic mapping (presented below; Yu et al. 2000) indicated that two separate genes are mutated in $d n d 1$ and $d n d 2$. Both $d n d$ lines exhibit a dwarf rosette phenotype and dramatic reduction of the macroscopically visible HR produced not only in response to $P$. syringae that express avrRpt 2 but also to $P$. syringae expressing avrRpml or $a v r B$ (Yu et al. 2000). Disruption of the HR controlled by more than one $a v r / R$ combination implied that the $d n d 2$ line carries a relatively general alteration of defense responses.

To confirm the absence of HR cell death in $d n d 2$ mutants, leaf tissues were examined by fluorescence microscopy to detect autofluorescence $24 \mathrm{~h}$ after pathogen inoculation. Wildtype Col- 0 and $d n d 2$ were inoculated with low and high concentrations of $P$. syringae pv. glycinea R4 that is nonvirulent on Arabidopsis Col-0, or P. syringae pv. glycinea R4 expressing avrRpt2, which elicits the HR on Arabidopsis plants that express RPS2. Figure 1 depicts the results for $d n d 2$ plants inoculated with the high bacterial titer and for control Col-0 plants inoculated at high or low bacterial titer as noted. $P$. syringae pv. glycinea R4 (no avr gene) applied at the low concentration $\left(5 \times 10^{5} \mathrm{CFU} / \mathrm{ml}\right)$ elicited only a background of isolated fluorescent flecks in Col-0 or $d n d 2$ leaves (data not shown). When plants were inoculated with $2 \times 10^{8} \mathrm{CFU} / \mathrm{ml}$ of 
P. syringae pv. glycinea R4 (no avr), a similar or slightly higher background of isolated fluorescent cells was observed (Fig. 1, upper panels). When $P$. syringae pv. glycinea R4 expressing avrRpt 2 was applied at $5 \times 10^{5} \mathrm{CFU} / \mathrm{ml}$, an elevated number of isolated fluorescent cells was observed in wild-type Col-0 (on average, roughly 2 to $20 \%$ of all cells; Fig. 1, lower left panel), as expected for the wild-type HR at this level of pathogen. The $d n d 2$ plants did not show this elevated rate of cell death. Inoculation with the high $2 \times 10^{8} \mathrm{CFU} / \mathrm{ml}$ concentration of $P$. syringae pv. glycinea $\mathrm{R} 4$ expressing avrRpt2 induced the expected strong HR in Col-0 (confluent autofluorescence and macroscopically visible tissue collapse; data not shown). However, most $d n d 2$ leaves displayed only the background of rare fluorescent cells at a rate similar to that observed in the $P$. syringae pv. glycinea $\mathrm{R} 4$ controls, even when subjected to $2 \times 10^{8} \mathrm{CFU} / \mathrm{ml}$ of $P$. syringae pv. glycinea R4 expressing avrRpt2 (Fig. 1, lower right panel). An increase in autofluorescent cell death relative to the no-avr control was observed in approximately one in ten $d n d 2$ leaves inoculated with $2 \times 10^{8} \mathrm{CFU} / \mathrm{ml}$ of $P$. syringae $\mathrm{pv}$. glycinea $\mathrm{R} 4$ expressing avrRpt 2 and then only in isolated areas that represented a fraction of the inoculated tissue.

In separate experiments, HR cell death was monitored using Evans blue dye to stain dead cells. Results were consistent with the data from fluorescence detection. The majority of the $d n d 2$ leaves examined showed little or no HR cell death over that observed in negative controls, but in a minority of leaves, patches of stained cells could be observed in a subset of the inoculated tissue (data not shown). Hence, as was previously observed for $d n d 1$ mutants (Yu et al. 1998), loss of HR in $d n d 2$ plants is widespread even at high pathogen titers but is quantitative rather than complete.

\section{The $d n d 2$ mutant retains gene-for-gene resistance.}

To test whether the suppression of HR in $d n d 2$ mutants is associated with a loss of disease resistance, the in planta growth of $P$. syringae pv. tomato DC3000 (virulent on Arabidopsis Col0 ) and $P$. syringae pv. tomato DC3000 expressing avrRpt2 (avirulent on Arabidopsis Col-0) was monitored in Col-0 and $d n d 2$ plants. The $d n d 2$ mutant limited the growth of $P$. syringae pv. tomato DC3000 avrRpt 2 similar to the Col-0 control plants, suggesting that $d n d 2$ plants retain gene-for-gene resistance in the avrRpt2/RPS2 pathway (Fig. 2). Similar results were observed for both avrRpml and avrB/RPMI pathways (Fig. 2 and data not shown). Resistance mediated by avrRPS4/RPS4 is intermediate in Col-0, and we noted that this resistance was enhanced reproducibly in $d n d 2$ plants (Fig. 2 and data not shown). The fact that restriction of growth of avirulent $P$. syringae pv. tomato DC3000 was substantially stronger than the restriction of virulent $P$. syringae pv. tomato DC3000 in $d n d 2$ plants confirms that gene-for-gene-mediated defense induction was operative despite the general absence of the HR.

\section{The $d n d 2$ line exhibits elevated resistance to virulent pathogens.}

Growth of virulent $P$. syringae pv. tomato DC3000 was reduced in $d n d 2$ plants, relative to the bacterial growth observed in wild-type Col-0 (Fig. 2). Disease symptoms were also reduced when $d n d 2$ plants were inoculated with $P$. syringae pv. tomato DC3000; necrotic lesions and surrounding chlorosis were observed in Col-0 leaves four to six days after inoculation, while leaves of the $d n d 2$ mutants were uniformly free of disease (data not shown). This is consistent with the observed reductions in bacterial growth and suggests that $d n d 2$ plants are in a state resembling SAR. The gene-for-gene resistance against avirulent $P$. syringae was stronger than the constitutive SAR-like resistance against virulent $P$. syringae (Fig. 2).
$P R-1$ gene expression is elevated yet inducible in $d n d 2$ plants.

A number of Arabidopsis constitutive defense mutants, such as the $d n d 1, c p r$, cim, and acd mutants, have been shown to exhibit constitutively elevated expression of some PR genes (Glazebrook 2001). We examined PR gene expression in $d n d 2$ plants. When blots of total RNA from leaf samples were hybridized with the $P R-1$ gene probe, no significant expression was observed in noninoculated Col-0 plants, but noninoculated $d n d 2$ mutants constitutively expressed $P R-1$ (Fig. 3 and data not shown). In Col-0, levels of $P R-1$ mRNA were induced $24 \mathrm{~h}$ after infection by $P$. syringae pv. tomato DC3000 and were induced to a greater extent in response to $P$. syringae pv. tomato DC3000 expressing avrRpt2 (Fig. 3 and data not shown). This trend of PR gene induction being stronger during incompatible responses than during compatible responses has been observed in numerous plant-pathogen interactions. In three of five independent experiments, mutant $d n d 2$ plants exhibited a substantial increase in $P R-1$ gene expression following inoculation with avirulent $P$. syringae, beyond the elevated basal levels of expression. In $d n d 2$ plants inoculated with virulent $P$. syringae pv. tomato DC3000 (and with DC3000 avrRpt $2^{+}$in two of the five experiments), $P R-1$ remained high relative to wild-type Col- 0 but exhibited minimal or no elevation relative to noninoculated $d n d 2$ plants. Overall, constitutively elevated resistance in $d n d 2$ plants was associated with constitutively elevated PR gene expression, and the gene-for-gene signal transduction that leads to stronger elevation of PR gene expression remained functional.

The $\boldsymbol{d} \boldsymbol{n} \boldsymbol{d} \mathbf{2}$ mutants have enhanced salicylic acid production.

SA has been shown to induce PR gene expression, and elevated levels of SA (endogenous or applied) can lead to broadspectrum resistance (Ryals et al. 1996). To investigate possible mechanisms for the elevated resistance and constitutively expressed PR genes in the $d n d$ mutants, we analyzed the SA content of leaf samples from $d n d 2$ plants. Levels of endogenous free SA and SA-glucoside from wild-type Col-0 and $d n d 2$ plants were determined. Figure 4 illustrates the high levels of free SA and SA-glucoside present in noninoculated $d n d 2$ plants as opposed to noninoculated wild-type Col-0 plants. Constitutively high SA levels provide at least a partial mecha-

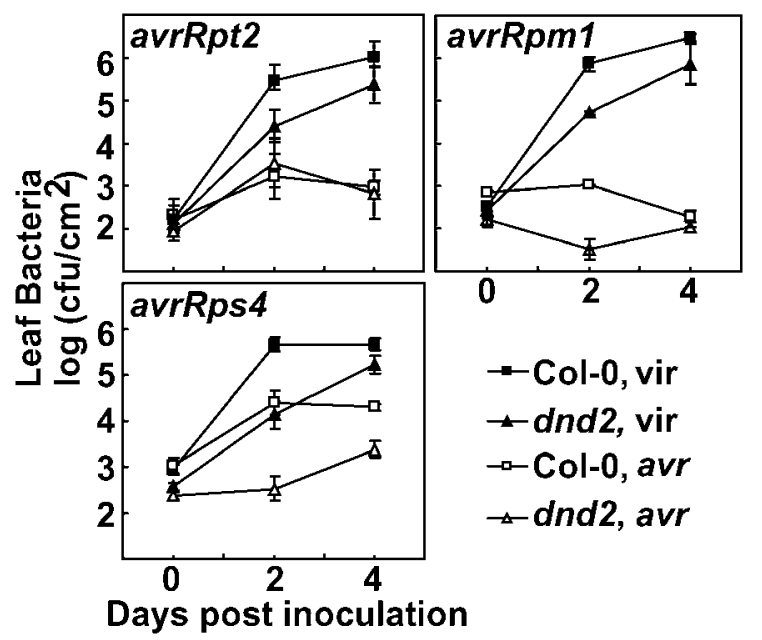

Fig. 2. The suppression of the hypersensitive response in $d n d 2$ plants does not lead to loss of gene-for-gene resistance, but the $d n d 2$ plants restrict growth of virulent bacteria to a greater extent than do wild-type plants. The growth of Pseudomonas syringae pv. tomato DC3000 carrying no avirulence gene (vir) or avrRpt2, avrRpm1, or avrRPS4 was assessed in Arabidopsis Col-0 and dnd2 plants. 
nistic explanation for the observed defense elevation state of dnd2 plants.

Expression of $n a h G$ in $d n d 2$ plants removes the constitutive PR gene expression and elevated resistance to virulent pathogens but not the loss of HR.

To place the $d n d 2$ mutation with respect to SA-mediated defense signaling pathways, $d n d 2$ plants containing the bacterial salicylate hydroxylase gene $\left(n a h G^{+}\right)$were generated. Expression of $n a h G^{+}$has been shown to effectively remove SA from plants (Gaffney 1993), but very recent work suggests that $n a h G^{+}$expression can block plant defense responses through SA-independent mechanisms as well (Heck et al. 2003; van Wees and Glazebrook 2003; discussed below). In the present study, homozygous $d n d 2$ plants were either crossed to the well-characterized Arabidopsis Col-0 nahG plant line B15 (Lawton et al. 1995) and progeny lines homozygous for the $d n d 2$ mutation and carrying the $n a h G^{+}$ gene were then identified. or homozygous $d n d 2 / d n d 2$ plants were transformed with the $35 \mathrm{~S}-n a h G^{+}$construct originally used to make line B15. The effect on the growth of virulent and avirulent $P$. syringae in $d n d 2$ plants was then tested. Expression of $n a h G^{+}$disrupted both the elevated partial resistance against a normally virulent pathogen as well as the gene-for-gene resistance against an avirulent pathogen (Fig. 5A). The loss of resistance to virulent and avirulent $P$. syringae correlated with a loss of constitutive $P R-1$ gene expression of $d n d 2$ plants expressing $n a h G^{+}$(Fig. 5B).
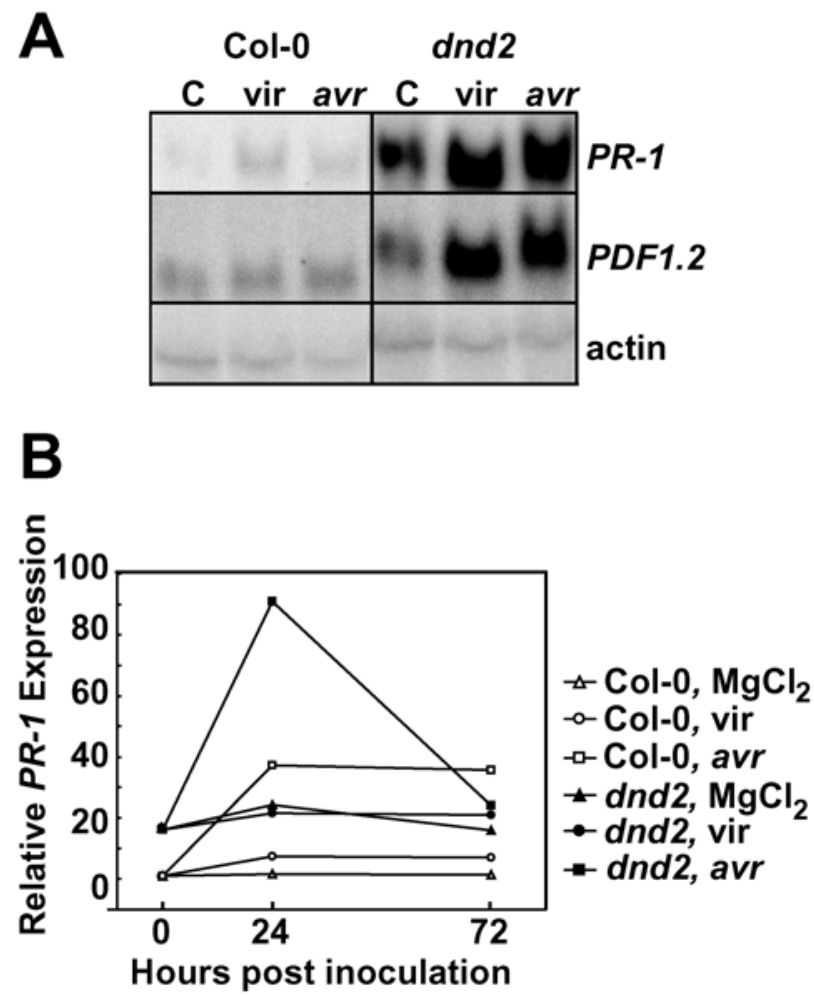

Fig. 3. $d n d 2$ plants exhibit constitutive $P R-1$ expression and pathogeninducible $P D F 1.2$ and $P R-1$ expression. Plants were inoculated with either Pseudomonas syringae pv. tomato DC3000 carrying no avirulence gene (vir) or avrRpt2 (avr) or were mock-inoculated $\left(\mathrm{MgCl}_{2}\right)$. A, Northern blot from one experiment, probed successively with $P R-1, P D F 1.2$, and actin (loading control). RNA was extracted $24 \mathrm{~h}$ after inoculation. B, $P R-1$ expression in a second, independent experiment. Blot was probed successively with $P R-1$ and $\beta$-ATPase (loading control), and the phosphorimager readout was quantified. Relative $P R-1 \mathrm{mRNA}$ levels were calculated by normalizing to $\beta$-ATPase mRNA level for that sample, with all samples then normalized to the noninoculated Col- $0 \mathrm{t}_{0}$ sample.
While removal of SA, other $n a h G^{+}$effects, or both greatly impacted the disease resistance phenotypes of $d n d 2$ plants, other $d n d 2$ phenotypes were not strongly affected. When rosette diameters were compared, homozygous dnd2/nah $G^{+}$ plants were significantly larger than $d n d 2$ plants but significantly smaller than wild-type Col-0 or $n a h G^{+}$plants (data not shown). The observation that $d n d 2 / n a h G^{+}$plants were still "semidwarfed" in leaf and rosette size despite SA removal indicated that factors beyond high SA levels affect the size of mutant $d n d 2$ plants.

Removal of SA from $d n d 2$ plants also only partially relieved the $\mathrm{HR}^{-}$phenotype. As previously reported (Yu et al. 1998), Col-0 plants developed a strong HR within $24 \mathrm{~h}$ after inoculation with $P$. syringae expressing avrRpt2, while the HR was delayed in Col-0/nah $G^{+}$plants and was apparent at $48 \mathrm{~h}$ but not $24 \mathrm{~h}$. The $d n d 2$ and $d n d 2 / n a h G^{+}$plant lines exhibited little or no macroscopically detectable HR at $24 \mathrm{~h}$. In four independent experiments, dnd2/nah $G^{+}$plants examined at $48 \mathrm{~h}$ either continued to show almost no HR or developed mild HR symptoms in only some leaves. Removal of SA via $n a h G^{+}$did not restore homozygous $d n d 2$ mutants to a $\mathrm{HR}^{+}$phenotype. As an example, Figure 5C shows the results of one experiment that used four independent homozygous $d n d 2 / n a h G^{+}$lines obtained via transformation of a $d n d 2$ parent. At $48 \mathrm{~h}$, the HR-associated tissue collapse was marginally more severe in two or three of the $d n d 2 / n a h G^{+}$lines relative to $d n d 2$ controls yet was still notably less severe than in Col-0 plants (Fig. 5C). In two of the $d n d 2 / n a h G^{+}$lines shown in Figure 5C, SA and SA-glucoside levels were measured. The $n a h G^{+}$transgene reduced SA levels to the limits of accurate detection in line a, but in dnd $2 / n a h G^{+}$line $\mathrm{b}$, the salicylate levels remained elevated as for $d n d 2$ (the average $\mathrm{SA}+$ salicylic acid-glucoside (SAG) content per g fresh weight was $4.0 \mu \mathrm{g} / \mathrm{g}$ for line $\mathrm{b}$ and $0.5 \mu \mathrm{g} / \mathrm{g}$ for line a). This correlated with the failure of the $n a h G^{+}$construct to alter HR responses in line b as opposed to the other $n a h G^{+}$lines. But even in cases, such as line a, when salicylate levels were significantly reduced by expression of the $n a h G^{+}$ transgene, the HR was only restored to $d n d 2$ mutant plants to a minor extent (Fig. 5C).

$\mathrm{JA}$-associated gene expression is activated in $\boldsymbol{d n d} \mathbf{2}$ plants.

In light of the above observation that some $d n d 2$ phenotypes are SA-independent, we examined the expression of the ethylene and JA-associated indicator gene PDF1.2. As also reported by others, PDF1.2 expression in wild-type Col-0 was minimal before and after infection by virulent or avirulent $P$. syringae. Noninoculated $d n d 2$ plants also did not exhibit much PDF1.2 expression (Fig. 3). Intriguingly and in contrast to Col-0, dnd2 plants exhibited substantial PDF1.2 expression upon treatment with virulent or avirulent $P$. syringae (Fig. 3).

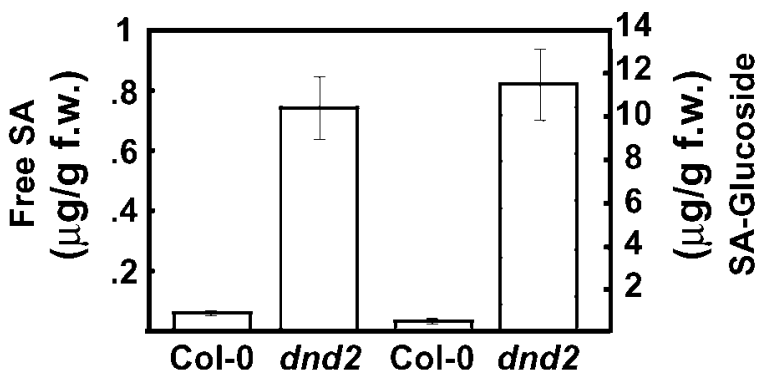

Fig. 4. $d n d 2$ plants exhibit elevated levels of salicylic acid (SA). Open bars (left y-axis) report free SA; hatched bars (right y-axis) report glucosideconjugated forms of SA in Col- 0 and $d n d 2$ plants. 


\section{DND2 encodes a cyclic nucleotide-gated ion channel,} AtCNGC4 (HLM1).

In order to isolate and characterize the gene responsible for the $d n d 2$ phenotypes, a genetic mapping project was carried out. Crosses of $d n d 2$ to wild-type Col-0 and No-0 ecotypes yielded $\mathrm{F}_{1}$ individuals that exhibited an $\mathrm{HR}^{+}$phenotype and were wild type in size. An $\mathrm{F}_{2}$ population from a $d n d 2 \times$ No- 0 cross segregated for $\mathrm{HR}^{+}: \mathrm{HR}^{-}$plants in a ratio that was consistent with a $3: 1$ ratio $\left(\chi^{2}=0.57, P=0.45\right)$, indicating that a single recessive locus is responsible for the $\mathrm{HR}^{-}$phenotype of $d n d 2$ plants. The dwarfed phenotype cosegregated with the $\mathrm{HR}^{-}$phenotype. Crosses between homozygous $d n d 1 / d n d 1$ and $d n d 2 / d n d 2$ plants also yielded $\mathrm{F}_{1}$ individuals that exhibited an $\mathrm{HR}^{+}$phenotype and wild-type size and appearance, indicating that these two mutant lines carry recessive mutations in separate genes.

The dnd2 phenotypes showed linkage to markers $L F Y 3$, nga129, and nga76, all of which map to the lower arm of chromosome 5, and were not linked to markers on any other chromosomes (data not shown). Approximately $1,100 \mathrm{~F}_{2}$ plants were prescreened for recombination events between flanking genetic markers nga129 and LFY3 (Fig. 6). Fine-mapping of the $D N D 2$ genetic interval was facilitated by screening an additional $500 \mathrm{~F}_{2}$ plants, using seven newly developed PCRbased markers (discussed below). Additional fine-mapping of $30 \mathrm{~F}_{2}$ lines that carried a crossover in this region delineated DND2 to the genetic interval between markers K19P17-H1 and MDK4-A, with three and one recombination events, respectively (Fig. 6). Based on the relatively small size of this genetic interval (approximately $200 \mathrm{~kb}$ ), a candidate gene approach was then taken to identify the DND2 gene.

Since DND1 encodes a CNG ion channel (AtCNGC2), we began our candidate gene approach by sequencing AtCGNC4 (At5g54250), a CNG ion channel family member located in the DND2 genetic interval. Sequence analysis revealed that dnd 2 plants contain a $\mathrm{G}$ to $\mathrm{A}$ point mutation at tryptophan (amino acid 89) leading to a premature stop codon in the first putative transmembrane-spanning domain of AtCGNC4. Sequence data were verified by developing a dCAPS marker that detects the $d n d 2-1$ mutation (discussed below). In order to confirm mapping and sequencing data, dnd2-1 plants were transformed with a binary vector containing wild-type AtCNGC4, driven by its native promoter. $\mathrm{T}_{1} d n d 2-1$ plants transformed with the AtCNGC4 construct exhibited rosettes that were comparable in size to that of wild-type Col-0 plants, whereas dnd2-1 plants (nontransformed) and $d n d 2-1$ lines transformed with the empty vector exhibited dwarf rosettes (Fig. 7). In addition to size complementation, HR assays performed on $\mathrm{T}_{1}$ lines demonstrated functional complementation of $d n d 2-1$ plants by AtCNGC4 (Fig. 7). All $d n d 2+A t C N G C 4$ $\mathrm{T}_{1}$ lines tested exhibited an $\mathrm{HR}$ in response to avirulent $P$. syringae.

The above data demonstrate that the mutant phenotypes of dnd 2 plants are caused by disruption of the gene encoding AtCNGC4. Recently, Balague and associates (2003) described the Arabidopsis hlml mutants in which AtCNGC4 is mutated and phenotypes similar to $d n d 2$ are observed. The $d n d 2$ and hlml mutations define the same gene, which previously had been designated AtCNGC4.

\section{DISCUSSION}

An earlier screen to identify unknown components of the avrRpt2-RPS2 disease resistance pathway of Arabidopsis produced mutants defective in the RPS2-mediated HR, most notably the well-characterized $d n d 1$ mutant (Clough et al. 2000; Yu et al. 1998, 2000). In this study, we sought to characterize the dnd 2 mutant line. We found that $d n d 2$ plants exhibit similar morphologies and disease phenotypes to dndl plants. Mapbased cloning revealed that $d n d 2$ phenotypes are due to loss of the CNGC4 cyclic nucleotide-gated ion channel protein, which is a strikingly similar result to the previous discovery that dnd1 phenotypes are caused by loss of CNGC2 (Clough et al. 2000). Like the $d n d l$ mutants, $d n d 2$ plants are dwarfed and fail to develop the HR in response to avirulent $P$. syringae yet carry out effective gene-for-gene resistance. Mutant $d n d l$ and $d n d 2$ plants also exhibit constitutively high expression of $P R$ 1 , elevated levels of SA, and display an elevated "SAR-like" resistance in response to virulent pathogens. The gene-forgene interactions that we tested typically signal for HR cell death, but the HR is somehow blocked in dnd plants. HR sup-
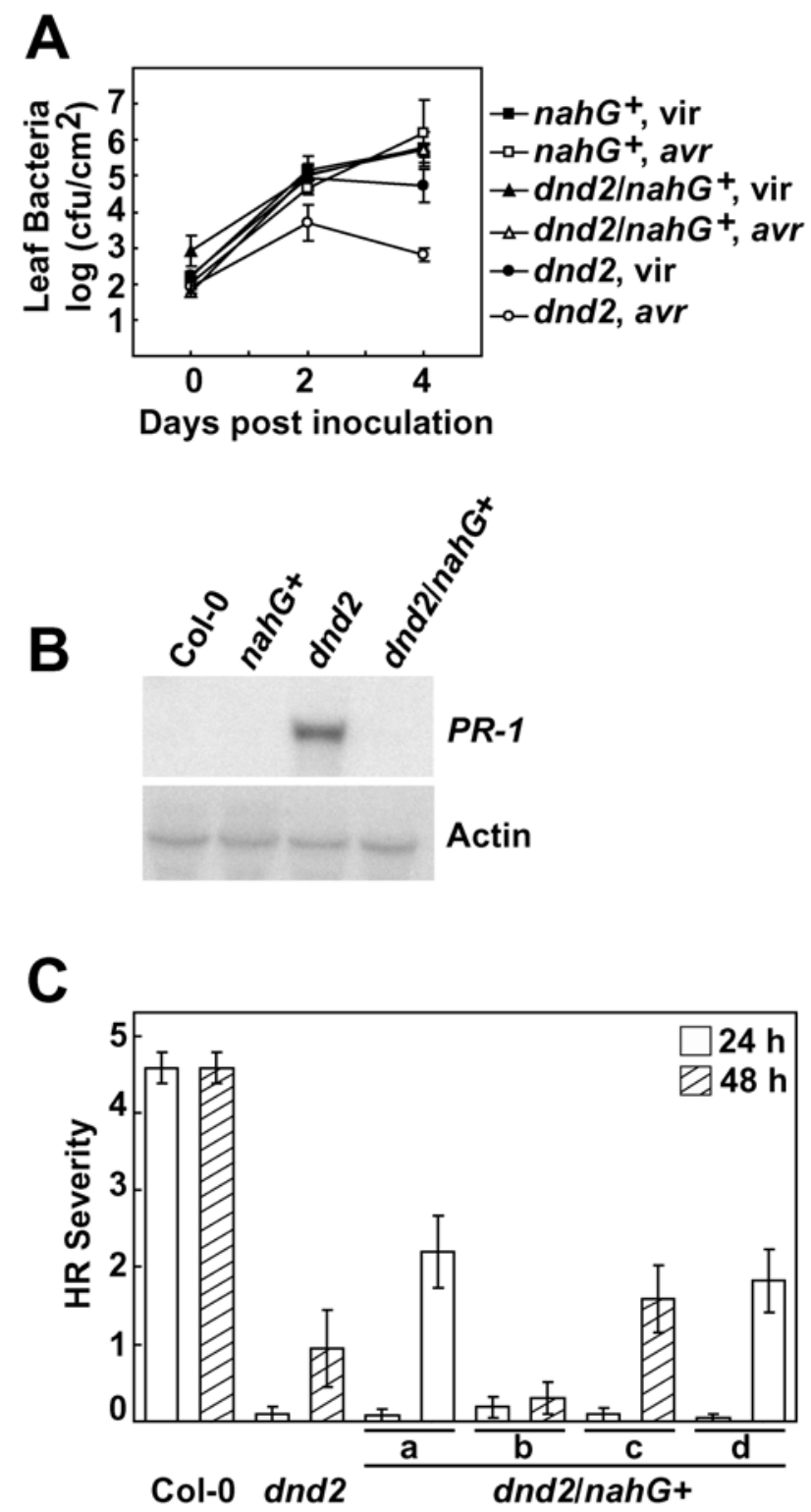

Fig. 5. A, Degradation of salicylic acid (SA) in $d n d 2$ plants by $n a h G^{+}$leads to the loss of disease resistance. Growth of Pseudomonas syringae pv. tomato DC3000 carrying no avirulence gene (vir) or avrRpt2 (avr) was assessed in $n a h G^{+}, d n d 2$ and $d n d 2 / n a h G^{+}$plants. B, $d n d 2$ plants that express $n a h G^{+}$lose constitutive $P R-1$ expression. RNA was isolated from noninoculated 1-month-old wild-type Col- $0, n a h G^{+}, d n d 2$, and $d n d 2 / n a h G^{+}$plants. C, Hypersensitive response (HR) development in four independent homozygous $d n d 2 / n a h G^{+}$lines (a, b, c, d) obtained via transformation of a $d n d 2$ parent. Note that SA and SA-glucoside levels were not effectively reduced in transgenic dnd2/nahG $G^{+}$line b. HR severity was rated 24 and $48 \mathrm{~h}$ after inoculation with $P$. syringae pv. glycinea $\mathrm{R} 4$ avrRpt $2^{+}$. 
pression and the other phenotypes are apparently caused by loss of CNG channel function, but the effect may be direct or relatively indirect. HR suppression may be the result of the constitutively activated defenses, but this would have to be via a relatively novel mechanism, as many other Arabidopsis mutants that exhibit constitutive defenses do not have the $\mathrm{HR}^{-}$ phenotype. Alternatively, the lesion that primarily causes HR disruption might secondarily lead to activated defenses. How the loss of CNG channels in $d n d 1$, dnd2, and hlml mutants disrupts the HR remains unclear; this will be the focus of future studies.

We tested the hypothesis that SA mediates many or all phenotypes of $d n d 2$ plants. SA is known to induce PR genes, and the induction of these genes could lead to the induced "SARlike" state of the $d n d 2$ plants. Removal of SA using the $n a h G^{+}$ transgene (Gaffney 1993; Lawton et al. 1995) rendered dnd2/nah $G^{+}$plants more susceptible to virulent and avirulent pathogens, as is also seen in wild-type plants expressing $n a h G^{+}$(Fig. 5A). Increased bacterial populations on $d n d 2 / n a h G^{+}$plants were correlated with the loss of constitutive $P R-1$ gene expression (Fig. 5B). These data were consistent with data obtained for $d n d 1 / n a h G^{+}$lines (Clough et al. 2000) and could imply that $\mathrm{SA}$ is required for the resistance to $P$. syringae observed in $d n d 2$ mutants. However, in light of recent findings by van Wees and Glazebrook (2003) and Heck and associates (2003), it remains possible that the loss of disease resistance in $d n d / n a h G^{+}$lines is only partially or not at all due to elimination of SA. Catechol excess in the cell (van Wees and Glazebrook 2003) or other catechol-independent effects of $n a h G^{+}$(Heck et al. 2003) may also play a role. We interpret all $n a h G^{+}$results with caution and have initiated study of sid2/dnd double mutants to further address the issue.

The $\mathrm{HR}^{-}$and dwarf phenotypes of $d n d 2$ plants appear to be more clearly attributable to a factor other than excessive SA. The $n a h G^{+}$transgene has pleiotropic impacts, but it does remove SA. Yet removal of SA from $d n d 2$ plants using $n a h G^{+}$ did not restore the wild-type HR; there was only some minor abatement of the $\mathrm{HR}^{-}$phenotype (Fig. 5C). The same was true for the dwarf phenotype of $d n d 2$ plants.

\section{Lower Arm of Chromosome 5}

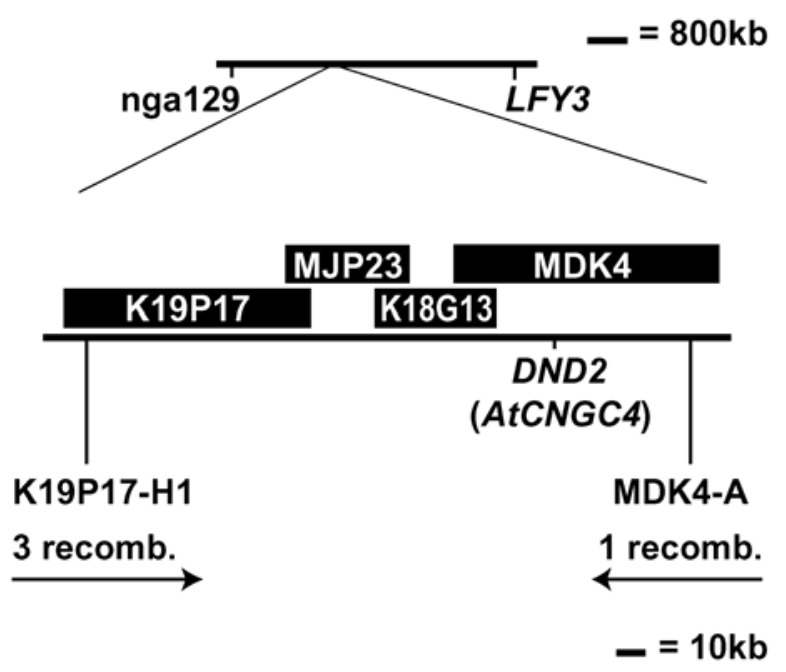

Fig. 6. Physical mapping of $D N D 2$ locus. The top line represents the genomic region on chromosome $\mathrm{V}$ between markers nga129 and $L F Y 3$, to which the DND2 locus was first mapped. The lower line represents approximately $200 \mathrm{~kb}$ from this region, delimited by the markers K19P17$\mathrm{H} 1$ and MDK4A. Rectangles denote BAC clones carrying genomic DNA that spans the smaller DND2 genetic interval. The number of recombination events identified between $d n d 2$ and each marker is noted.
One can postulate that SA removal would have restored the HR to $d n d$ mutants but other pleiotropic $n a h G^{+}$effects then made the HR go away again. This, however, seems inconsistent with data for other Arabidopsis mutants. The introduction of $n a h G^{+}$or $n p r l$ into another $\mathrm{HR}^{-}$mutant, agd2, caused loss of disease resistance in response to $P$. syringae expressing avrRpml but restored the HR (Rate and Greenberg 2001). In an acd6 genetic background, $n a h G^{+}$completely relieved the dwarf rosette phenotype, suppressed disease resistance to P. syringae, and restored the HR (Rate et al. 1999). The double mutant acd6 nprl was only partially susceptible to $P$. syringae, suggesting the involvement of an NPRl-independent pathway (Rate et al. 1999). Furthermore, introducing $n a h G^{+}$or $n p r l$ into the $\mathrm{HR}^{-}$background of the $h r l l$ mutant completely restored the ability to elicit the HR (Devadas and Raina 2002). The HR was only restored in those hrll nprl plants that did not exhibit a lesion-mimic phenotype (Devadas and Raina 2002). The disease resistance pheno-

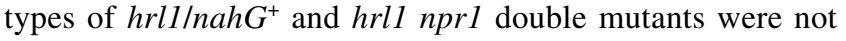
reported (Devadas and Raina 2002; Devadas et al. 2002). Based on the above differences, agd2, hrll, dndl, and $d n d 2$ $(h \operatorname{lml})$ appear to suppress the HR at different points of the cell death signaling cascade.

The persistence of the $\mathrm{HR}^{-}$phenotype in $d n d 2 / n a h G^{+}$plants suggested that SA-independent pathways are also activated in dnd plants. The SA-independent defense activation pathways that signal through ethylene and JA have received considerable attention in recent years (Conrath et al. 2002; Pieterse and van Loon 1999). These pathways, which had first been implicated in wound- and insect-induced responses, also mediate activation of some pathogen-inducible genes and ISR (Conrath et al. 2002; Thomma et al. 1999). PDF1.2 has become a standard marker for ethylene- and JA-dependent defense pathways (Penninckx et al. 1996) and was used in the present study to characterize $d n d 2$ plants (Fig. 3). In contrast to wild-type Arabidopsis Col-0, PDF1.2 gene expression levels were significantly induced in $d n d 2$ plants that had been infected with either virulent or avirulent $P$. syringae. This suggests that mutation of DND2 (AtCNGC4) primes the plant to respond to

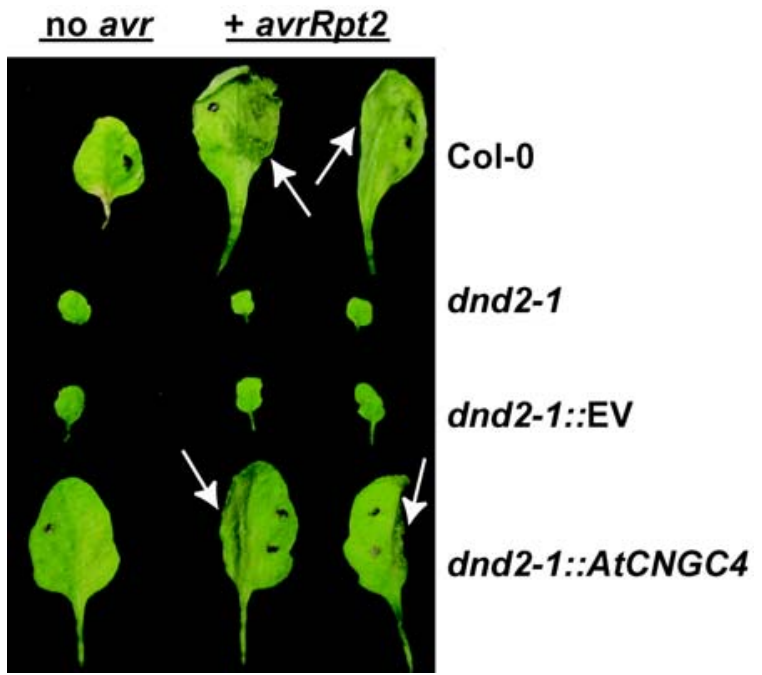

Fig. 7. Functional complementation of $d n d 2-1$ with AtCNGC4. dnd2-1 plants were transformed with an empty vector (EV) or with AtCNGC4 under the control of its native promoter. The photograph was taken $48 \mathrm{~h}$ after Col-0 and $d n d 2-1:: A t C N G C 4$ plants were inoculated with Pseudomonas syringae pv. glycinea R4 pVSP61 (no avr) or pV288 (avrRpt2) to assess the hypersensitive response (HR). dnd2-1 and $d n d 2-1:: \mathrm{EV}$ plants were not inoculated, due to their small size. Arrows point to regions on Col-0 and dnd2-1::AtCNGC4 leaves that exhibit the HR. 
invading pathogens with both SA-dependent and JA- and ethylene-dependent defense responses. Activation of SA pathways has previously been shown to reduce flux through JAdependent pathways, due in part to competition for the regulatory protein NPR1 (Heil and Bostock 2003; Spoel et al. 2003), making the dual effect of the $d n d 2$ mutation unusual (constitutive SA together with $P$. syringae-inducible JA pathways) (Van Wees et al. 2000). Large-scale expression profiling studies did reveal sets of genes that are activated by both SA and JA treatment (Schenk et al. 2000). However, simultaneous activation of $P R-1$ and PDF1.2, two genes that are often used to report SA and ethylene and JA signaling, respectively, suggests that additional cell signaling networks may be activated in $d n d 2$ plants following infection by $P$. syringae. Balague and associates (2003) did not observe any increase in PDF1.2 gene expression in $h l m l$ plants in response to an avirulent Xanthomonas strain, possibly because the pathogen-induced PDF1.2 activation in AtCNGC4 mutants may be pathogen specific.

Following the discovery that $d n d l$ phenotypes are caused by mutation of AtCNGC2 (Clough et al. 2000), it is interesting that AtCNGC4 is now similarly implicated in plant defense signaling (this study; Balague et al. 2003). Animal CNG ion channels are generally semiselective cation channels (Zagotta and Siegelbaum 1996). Recent studies with Arabidopsis CNG channels have revealed the multiple ions that these channels conduct and either regulate the levels of, are regulated by, or both. Recent studies are also revealing the multiple roles that CNG channels play in normal plant physiology. Leng and associates (2002) have shown that heterologous expression of AtCNGC2 (DNDI) allows cyclic nucleotide-dependent conductance of $\mathrm{K}^{+}$and $\mathrm{Ca}^{2+}$ but discriminates against $\mathrm{Na}^{+}$, whereas AtCNGCl equally conducts $\mathrm{K}^{+}$and $\mathrm{Na}^{+}$in human embryonic kidney cell lines (Hua et al. 2003). Preliminary electrophysiology studies of AtCNGC4 (DND2/HLM1) demonstrated conductance of both $\mathrm{K}^{+}$and $\mathrm{Na}^{+}$in a cyclic nucleotide-dependent fashion (Balague et al. 2003). Whole plant phenotypes have also been examined. Seedlings containing a TDNA insertion in AtCNGCl exhibited greater tolerance to increasing concentrations of lead (Sunkar et al. 2000). Plants with mutations in $A t C N G C 2$ displayed $\mathrm{Ca}^{2+}$ hypersensitivity in agar media or in soil carrying physiologically normal levels of $\mathrm{Ca}^{2+}$, and these plants did not exhibit $\mathrm{K}^{+}$or $\mathrm{Na}^{+}$hypersensitivity (Chan et al. 2003). Also relevant to calcium homeostasis, calmodulin-binding domains are common in CNG ion channels and calmodulin binding has been demonstrated for AtCNGC1 and AtCNGC2 (Kohler and Neuhaus 2000; Kohler et al. 1999). AtCNGC2 (DND1) is a necessary component for normal plant development (Chan et al. 2003; Yu et al. 1998). An association of AtCNGC2 with cell death events was suggested not only in studies of $d n d l$ mutants (Clough et al. $2000)$ but also in $\beta$-glucuronidase reporter fusion studies that showed that $A t C N G C 2(D N D 1)$ is expressed in plant regions exhibiting dehiscence or senescence (Kohler et al. 2001). The CNG ion channel family in Arabidopsis contains 20 members, including DND1 and DND2 (HLM1) (Maser et al. 2001).

It is intriguing that $d n d 1$ and $d n d 2$, mutations in two different but related ion channels, yield plants with strikingly similar phenotypes. The mutant phenotypes of homozygous mutant $d n d 1$ or $d n d 2$ plants, which carry the wild-type allele of the other dnd locus, suggest that DND1 (AtCNGC2) and DND2 (AtCNGC4) are not functionally redundant. Although the two proteins are only $56 \%$ similar, in phylogenetic trees AtCNGC2 and AtCNGC4 are more closely related to each other than to any of the other predicted CNG ion channel gene products (Kohler et al. 1999; Maser et al. 2001; Talke et al. 2003). It is possible that the two proteins form a heterotetramer channel, as demonstrated in olfactory and visual or- gan systems (Kaupp and Seifert 2002; Trudeau and Zagotta 2003) and that disruption of any part of this ion channel complex leads to the $\mathrm{HR}^{-}$/constitutive-SAR phenotype. Massively parallel signature sequencing (MPSS) data indicate that the two genes are both expressed in shoot tissue (Talke et al. 2003). However, the two proteins may function independently. As also suggested in the discussion by Balague and associates (2003), localized differences in the site or timing of gene expression, channel regulation, or channel ion specificity may account for the failure of DND1 (AtCNGC2) and DND2 (AtCNGC4) to exhibit functional redundancy. The wild-type appearance and $\mathrm{HR}^{+}$phenotypes that we observed in DND1/dnd1, DND2/dnd2 double heterozygote plants demonstrate that simultaneous reduction of gene dosage at both loci is not sufficient to cause obvious phenotypic defects, but complete loss of either channel protein causes dnd phenotypes. Preliminary data suggest that loss of both channels has an additive impact. $\mathrm{F}_{2}$ progeny from $d n d 2 / d n d 2 \times$ dndl/dndl crosses included plants, appearing at very roughly a $1 / 16$ rate, that exhibited a pronounced extreme dwarf, "super- $d n d$ " compact and curled leaf phenotype distinct from the phenotypes of dnd1 or $d n d 2$ single mutants (I. Yu, G. I. Jurkowski, and A. F. Bent, unpublished data). This latter finding must be regarded as preliminary, because the putative $d n d 1 / d n d 1$, dnd $2 / d n d 2$ double mutant plants grew extremely poorly, were generally infertile, and were not studied further. The main point remains, however, that loss of either relatively similar protein causes similar phenotypes, yet the proteins are not functionally redundant. The identification of two separate CNG ion channelencoding genes for which a mutation causes loss of the HR raises the testable hypothesis that mutations in some of the other 18 putative CNG ion channel genes may result in similar defense phenotypes.

It remains to be determined whether or not wild-type $\mathrm{CNG}$ ion channels play a relatively direct regulatory role in plant defense activation in nonmutant plants. Regardless, the disruption of ion-mediated cellular regulation caused by the $d n d l$ or $d n d 2$ mutations offers a useful tool for further dissection of the events that control plant defense activation and generation of HR cell death.

\section{MATERIALS AND METHODS}

\section{Plant growth conditions.}

Arabidopsis plants were planted in Sunshine Mix \#1 (Sun Gro Horticulture, Bellevue, WA, U.S.A.) and were grown in growth chambers or growth rooms at $22^{\circ} \mathrm{C}$ under short-day conditions (9-h light/15-h dark). Plants were fertilized by bottom watering with dilute Miracle-Gro (Scotts-Miracle-Gro Products, Marysville, OH, U.S.A.) on a weekly basis. A lesion mimic phenotype has been observed in some batches of $d n d 2$ plants, but its appearance is environmentally dependent and occurs very rarely in our growth conditions. The $d n d 2$ plants used in the present studies did not exhibit macroscopically visible lesion mimic phenotypes.

\section{Macroscopic and microscopic HR assays.}

P. syringae pv. glycinea Race 4 carrying avrRpt 2 (pV288) or vector alone (pVSP61) was used (Kunkel et al. 1993; Yu et al. 1993). Leaves were inoculated with $5 \times 10^{5}$ or $2 \times 10^{8} \mathrm{CFU}$ per $\mathrm{ml}$ of $P$. syringae pv. glycinea $\mathrm{R} 4 \mathrm{pV} 288$ or $P$. syringae $\mathrm{pv}$. glycinea $\mathrm{R} 4 \mathrm{pVSP} 61$, using 1-ml plastic syringes with no needle. For high-titer inoculations that induce confluent HR across the inoculated region, the HR was scored visually on a 0 to 5 scale based on leaf tissue collapse $(0=$ no collapse, $5=$ complete collapse) (Klement 1964). For fluorescence microscopy, the inoculated leaves were removed from plants $24 \mathrm{~h}$ 
after inoculation and were fixed in FAA (2\% formaldehyde, $5 \%$ acetic acid, $40 \%$ ethanol) for $15 \mathrm{~min}$. The fixed tissues were sequentially washed with $50 \%$ and then $95 \%$ ethanol to remove chlorophyll (Yu et al. 1993). Leaf parenchyma cells were observed by fluorescence microscopy, using a fluorescein filter set (Ex $495 \pm 20 \mathrm{~nm}, \mathrm{Em}>505 \mathrm{~nm}$ ) (Klement 1990). Evans Blue staining was performed as previously described (Yu et al. 1998).

\section{Bacterial growth assay in plants.}

Bacterial growth within leaves was monitored by vacuum infiltration of leaves with $10 \mathrm{mM} \mathrm{MgCl}$ with $1 \times 10^{5} \mathrm{CFU} / \mathrm{ml}$ $P$. syringae pv. tomato DC3000 carrying either avrRpt2, avrRpm1, avrRPS4, or no $a v r$ gene, followed by dilution-plating of homogenized leaf tissue on selective media as previously described (Yu et al. 1998).

\section{Gene expression studies.}

Plants were vacuum-infiltrated with $1 \times 10^{5} \mathrm{CFU}$ per $\mathrm{ml}$ of P. syringae pv. tomato DC3000 carrying either avrRpt2 or no avr gene. After infiltration, plants were returned to the growth chamber and above-ground plant tissue was collected $24 \mathrm{~h}$ after inoculation. Total RNA was extracted using Trizol (Invitrogen Corp., Carlsbad, CA, U.S.A.) according to manufacturer's instructions. $P R-1$ and $P D F 1.2$ probes were amplified using primers 5'-GTAGGTGCTCTTGTTCTTCCC, 5'-CAC ATAATTCCCACGAGGATC, 5'-TCATGGCTAAGTTTGCT TCC, and 5'-AATACACACGATTTAGCACC, respectively. Primers for actin loading control were 5'-AGGTTCTGTTC CAG and 5'-TTAGAAGCATTTCC. RNA blot assays and other molecular biology methods were as described (Ausubel 1998).

\section{Quantification of salicylic acid.}

Both free SA and SAG were quantified from noninoculated leaf tissue as described (Uknes et al. 1993). Between 0.2 and $0.5 \mathrm{~g}$ of leaf tissue per sample was utilized.

\section{Construction of $d n d 2 / n \mathrm{a} h G^{+}$lines.}

Homozygous $d n d 2$ plants were crossed to the characterized Col-0 homozygous $n a h G^{+}$line B15 (obtained from CIBAGeigy/Syngenta, Research Triangle Park, NC, U.S.A.) (Lawton et al. 1995). $\mathrm{F}_{1}$ progeny from this cross were selfed, and homozygous dnd2/nah $G^{+} \mathrm{F}_{2}$ lines were verified based on genetic segregation of $\mathrm{F}_{3}$ and $\mathrm{F}_{4}$ progeny. Plants were tested for homozygosity of $n a h G^{+}$transgene by plating on Murashige-Skoog agar medium containing $50 \mu \mathrm{g}$ of kanamycin per $\mathrm{ml}$. The $d n d 2$ phenotype was apparent from the size of plants grown on soil, as rosette size was either consistently large, consistently medium-small, or segregated 3:1 (large/mediumsmall) in $n a h G^{+}$plant lines. Additional $d n d 2 / n a h G^{+}$lines were generated by Agrobacterium floral dip transformation (Clough and Bent 1998) of $d n d 2$ plants with pCIB200 expressing $n a h G$ (Lawton et al. 1995).

\section{Mapping.}

Genetic mapping was carried out using DNA from $\mathrm{F}_{2}$ individuals or $\mathrm{F}_{3}$ families derived from crosses of Col-0 $($ dnd2/dnd2) $\times$ No-0. PCR-based cleaved amplified polymorphic sequence (CAPS) markers and simple sequence length polymorphism (SSLP) markers that cover the Arabidopsis genome were used for initial linkage analysis (Bell and Ecker 1994; Konieczny and Ausubel 1993). To narrow down the genetic interval that contained the DND2 locus, restriction fragment length polymorphism markers g4130, m233, mi69, and g3844 were used (Lister 1993; Liu et al. 1996; Nam et al. 1989). In addition, several new PCR-based markers detecting
Col-0/No-0 polymorphisms were designed during the course of DND2 map-based cloning. New SSLP and CAPS markers (named according to BAC clone) are as follows, MXC20-AT (5'-AGCCAAACGGAGAAGTTTGT, 5'-TCAACACGAAAT TACCCCAAT), MFH8-AT (5'- AAGTGGTTTTTGGATTTG GTTT, 5' - TTGGGAGAAATGGTTTTCCTT), K19E1-1A (5'AACATTCCCCGTTCCCTATC, 5'- CTGTCTTGCCCACCA AGTTT), MNC6-A (5'- GGAAGAAATGATTCTCTGTATTT CTCA, 5'- TGATTCATCTCTGTAATGCAAACC), MGN6B2 (5'-TCTTGCAAAATGGGAGGTTC, 5'-AGCTCCCAGTT GCAGAAAAG) (BamHI polymorphism), K19P17-H1 (5'-GC ATTGGATTTGGGAAAGAA, 5'-CATCCCACAGGGGATTT ATG) (MboI polymorphism), MDK4-A (5'- TTGACAATTTG TTAGCCTTGGA, 5'- GGAACCAGCGAAACCCTAAT), and K13P22-CTT (5' - TTCGTAAATTCGTCTGCTTGA, 5' - ACC TGTACGTTGCCCAAGTT). The $d n d 2-1$ mutation was verified using dCAPS primers 5'-TCCAAATGGGTTCGAGC AT and 5'-GCAATCTTGAACTGAATCC, which generates a new NlaIII site in the PCR product (Michaels and Amasino 1998; Neff et al. 1998).

\section{Complementation.}

Three independent PCR products of AtCNGC4 (At5g54250) were generated from Col-0 genomic DNA using primers (5'CGTGGTGAGACCAAAAATGA, 5' - CGACAAGGATCACA TTCAACA) and the Expand Long Template PCR system (Roche Applied Science, Indianapolis, IN, U.S.A.). Primers annealed $1.3 \mathrm{~kb}$ upstream and $0.7 \mathrm{~kb}$ downstream of the AtCNGC4 open reading frame. Independent PCR products were directly cloned using the Zero Blunt TOPO PCR cloning kit (Invitrogen) and then were digested with PstI and BamHI and were cloned into the binary vector pCAMBIA 3300 . Transformation of $d n d 2-1$ plants with AtCNGC4 constructs was performed by floral dip, as previously described (Clough and Bent 1998). $\mathrm{T}_{1}$ seeds were sterilized and plated on selection plates containing either phosphinothricin $(10 \mu \mathrm{g} / \mathrm{liter})$ and carbencillin (500 $\mu \mathrm{g} /$ liter) or phosphinothricin alone. Resistant seedlings were transplanted directly into soil. Putative $d n d 2$ $1:: A t C N G C 4$ lines that exhibited wild-type size rosettes were verified using a dCAPS marker for the $d n d 2-1$ mutation and for the PCAMBIA 3300-derived bar gene. HR phenotypes of dnd2-1::AtCNGC4 lines were determined by inoculating $\mathrm{T}_{1}$ lines with ( $P$. syringae pv. glycinea R4 pVSP61 (no avr) or pV288 (+avrRpt2) at an optical density at $600 \mathrm{~nm}$ value equal to 0.1 .

\section{ACKNOWLEDGMENTS}

We thank S. Miller as well as The Arabidopsis Information Resource, The Institute for Genome Research, and Arabidopsis Biological Resource Center groups for technical assistance during map-based cloning and complementation of $d n d 2$, L. Friedrich for assistance with the SA measurements shown in Figure 3, and J. Kramer and L. Hummel for greenhouse assistance. Work in the Bent lab was supported by grants from Novartis/Syngenta and from the United States Department of Agriculture-NRI program.

\section{LITERATURE CITED}

Aarts, N., Metz, M., Holub, E., Staskawicz, B. J., Daniels, M. J., and Parker, J. E. 1998. Different requirements for EDS1 and NDR1 by disease resistance genes define at least two $R$ gene-mediated signaling pathways in Arabidopsis. Proc. Natl. Acad. Sci. U.S.A. 95:1030610311.

Alvarez, M. E., Pennell, R. I., Meijer, P. J., Ishikawa, A., Dixon, R. A., and Lamb, C. 1998. Reactive oxygen intermediates mediate a systemic signal network in the establishment of plant immunity. Cell 92:773-784.

Balague, C., Lin, B., Alcon, C., Flottes, G., Malmstrom, S., Kohler, C., Neuhaus, G., Pelletier, G., Gaymard, F., and Roby, D. 2003. HLM1, an essential signaling component in the hypersensitive response, is a 
member of the cyclic nucleotide-gated channel ion channel family. Plant Cell 15:365-379.

Beers, E. P., and McDowell, J. M. 2001. Regulation and execution of programmed cell death in response to pathogens, stress and developmental cues. Curr. Opin. Plant Biol. 4:561-567.

Bell, C. J., and Ecker, J. R. 1994. Assignment of 30 microsatellite loci to the linkage map of Arabidopsis. Genomics 19:137-144.

Bendahmane, A., Kanyuka, K., and Baulcombe, D. C. 1999. The $R x$ gene from potato controls separate virus resistance and cell death responses. Plant Cell 11:781-792.

Bowling, S. A., Guo, A., Cao, H., Gordon, A. S., Klessig, D. F., and Dong, X. 1994. A mutation in Arabidopsis that leads to constitutive expression of systemic acquired resistance. Plant Cell 6:1845-1857.

Chan, C. W., Schorrak, L. M., Smith, R. K., Jr., Bent, A. F., and Sussman, M. R. 2003. A Cyclic nucleotide-gated ion channel, CNGC2, is crucial for plant development and adaptation to calcium stress. Plant Physiol. 132:728-731

Chivasa, S., and Carr, J. P. 1998. Cyanide restores $N$ gene-mediated resistance to Tobacco mosaic virus in transgenic tobacco expressing salicylic acid hydroxylase. Plant Cell 10:1489-1498.

Clough, S. J., and Bent, A. F. 1998. Floral dip: A simplified method for Agrobacterium-mediated transformation of Arabidopsis thaliana. Plant J. 16:735-743.

Clough, S. J., Fengler, K. A., Yu, I. C., Lippok, B., Smith, R. K., Jr., and Bent, A. F. 2000. The Arabidopsis dnd1 "defense, no death" gene encodes a mutated cyclic nucleotide-gated ion channel. Proc. Natl. Acad. Sci. U.S.A. 97:9323-9328.

Conrath, U., Pieterse, C. M., and Mauch-Mani, B. 2002. Priming in plantpathogen interactions. Trends Plant Sci. 7:210-216.

Dangl, J. L., and Jones, J. D. 2001. Plant pathogens and integrated defence responses to infection. Nature 411:826-833.

del Pozo, O., and Lam, E. 1998. Caspases and programmed cell death in the hypersensitive response of plants to pathogens. Curr. Biol. 8:1129-1132.

Delaney, T. P., Uknes, S., Vernooij, B., Friedrich, L., Weymann, K. Negrotto, D., Gaffney, T., Gut-Rella, M., Kessmann, H., Ward, W., and Ryals, J. 1994. A central role of salicylic acid in plant disease resistance. Science 266:1247-1250.

Delledonne, M., Zeier, J., Marocco, A., and Lamb, C. 2001. Signal interactions between nitric oxide and reactive oxygen intermediates in the plant hypersensitive disease resistance response. Proc. Natl. Acad. Sci. U.S.A. 98:13454-13459.

Devadas, S. K., and Raina, R. 2002. Preexisting systemic acquired resistance suppresses hypersensitive response-associated cell death in Arabidopsis hrl1 mutant. Plant Physiol. 128:1234-1244.

Devadas, S. K., Enyedi, A., and Raina, R. 2002. The Arabidopsis hrl1 mutation reveals novel overlapping roles for salicylic acid, jasmonic acid and ethylene signaling in cell death and defence against pathogens. Plant J. 30:467-480.

Dietrich, R. A., Delaney, T. P., Uknes, S. J., Ward, E. R., Ryals, J. A., and Dangl, J. L. 1994. Arabidopsis mutants simulating disease resistance response. Cell 77:565-577.

Dixon, R. A., and Harrison, M. J. 1994. Early events in the activation of plant defense responses. Annu. Rev. Phytopathol. 32:479-501.

Dong, X. 1998. SA, JA, ethylene, and disease resistance in plants. Curr Opin. Plant Biol. 1:316-323.

Dong, X. 2001. Genetic dissection of systemic acquired resistance. Curr Opin. Plant Biol. 4:309-314.

Dorey, S., Baillieul, F., Pierrel, M., Saindrenan, P., Fritig, B. and Kauffmann, S. 1997. Spatial and temporal induction of cell death, defense genes, and accumulation of salicylic acid in tobacco leaves reacting hypersensitively to a fungal glycoprotein elicitor. Mol. PlantMicrobe Interact. 10:646-655.

Gaffney, T., Friedrich, L., Vernooji, B., Negrotto, D., Nye, G., Uknes, S. Ward, R., Kessmann, H., and Ryals, J. 1993. Requirement of salicylic acid for the induction of systemic acquired resistance. Science 261:754-756

Glazebrook, J. 2001. Genes controlling expression of defense responses in Arabidopsis-2001 status. Curr. Opin. Plant Biol. 4:301-308.

Govrin, E. M., and Levine, A. 2000. The hypersensitive response facilitates plant infection by the necrotrophic pathogen Botrytis cinerea. Curr. Biol. 10:751-757.

Greenberg, J. T., and Ausubel, F. M. 1993. Arabidopsis mutants compromised for the control of cellular damage during pathogenesis and aging. Plant J. 4:327-341.

Heath, M. C. 2000. Hypersensitive response-related death. Plant Mol. Biol. 44:321-334

Heck, S., Grau, T., Buchala, A., Metraux, J.-P., and Nawrath, C. 2003. Genetic evidence that expression of NahG modifies defence pathways independent of salicylic acid biosynthesis in the Arabidopsis-Pseudomonas syringae pv. tomato interaction. Plant J. 36:342-352.
Heil, M., and Bostock, R. M. 2002. Induced systemic resistance (ISR) against pathogens in the context of induced plant defences. Ann. Bot. (Lond). 89:503-512.

Hildmann, T., Ebneth, M., Pena-Cortes, H., Sanchez-Serrano, J. J., Willmitzer, L., and Prat, S. 1992. General roles of abscisic and jasmonic acids in gene activation as a result of mechanical wounding. Plant Cell 4:1157-1170.

Hua, B. G., Mercier, R. W., Leng, Q., and Berkowitz, G. A. 2003. Plants do it differently. A new basis for potassium/sodium selectivity in the pore of an ion channel. Plant Physiol. 132:1353-1361.

Jirage, D., Zhou, N., Cooper, B., Clarke, J. D., Dong, X., and Glazebrook, J. 2001. Constitutive salicylic acid-dependent signaling in cprl and cpr6 mutants requires PAD4. Plant J. 26:395-407.

Kaupp, U. B., and Seifert, R. 2002. Cyclic nucleotide-gated ion channels. Physiol. Rev. 82:769-824.

Klement, Z., Farkas, G. I. and Lovrekovich, L. 1964. Hypersensitive reaction induced by phytopathogenic bacteria in the tobacco leaf. Phytopathology 54:474-477.

Klement, Z., Stall, R. E., Novacky, A., Ersek, T., Fett, W., Huang, J., and Beckman, C. 1990. Methods in Phytobacteriology. H. Stillman, Budapest.

Klessig, D. F., Durner, J., Noad, R., Navarre, D. A., Wendehenne, D., Kumar, D., Zhou, J. M., Shah, J., Zhang, S., Kachroo, P., Trifa, Y., Pontier, D., Lam, E., and Silva, H. 2000. Nitric oxide and salicylic acid signaling in plant defense. Proc. Natl. Acad. Sci. U.S.A. 97:8849-8855.

Kohler, C., and Neuhaus, G. 2000. Characterisation of calmodulin binding to cyclic nucleotide-gated ion channels from Arabidopsis thaliana. FEBS (Fed. Eur. Biochem. Soc.) Lett. 471:133-136.

Kohler, C., Merkle, T., and Neuhaus, G. 1999. Characterisation of a novel gene family of putative cyclic nucleotide- and calmodulin-regulated ion channels in Arabidopsis thaliana. Plant J. 18:97-104.

Kohler, C., Merkle, T., Roby, D., and Neuhaus, G. 2001. Developmentally regulated expression of a cyclic nucleotide-gated ion channel from Arabidopsis indicates its involvement in programmed cell death. Planta 213:327-332.

Kohm, B. A., Goulden, M. G., Gilbert, J. E., Kavanagh, T. A., and Baulcombe, D. C. 1993. A Potato virus $X$ resistance gene mediates an induced, nonspecific resistance in protoplasts. Plant Cell 5:913-920.

Konieczny, A., and Ausubel, F. M. 1993. A procedure for mapping Arabidopsis mutations using co-dominant ecotype-specific PCR-based markers. Plant J. 4:403-410.

Kunkel, B. N., Bent, A. F., Dahlbeck, D., Innes, R. W., and Staskawicz, B. J. 1993. RPS2, an Arabidopsis disease resistance locus specifying recognition of Pseudomonas syringae strains expressing the avirulence gene avrRpt2. Plant Cell 5:865-875.

Lawton, K., Weymann, K., Friedrich, L., Vernooij, B., Uknes, S., and Ryals, J. 1995. Systemic acquired resistance in Arabidopsis requires salicylic acid but not ethylene. Mol. Plant Microbe Interact. 8:863-870.

Leng, Q., Mercier, R. W., Hua, B. G., Fromm, H., and Berkowitz, G. A 2002. Electrophysiological analysis of cloned cyclic nucleotide-gated ion channels. Plant Physiol. 128:400-410.

Lister, C., and Dean, C. 1993. Recombinant inbred lines for mapping RFLP and phenotypic markers in Arabidopsis thaliana. Plant J. 4:745-750.

Liu, Y. G., Mitsukawa, N., Lister, C., Dean, C., and Whittier, R. F. 1996. Isolation and mapping of a new set of 129 RFLP markers in Arabidopsis thaliana using recombinant inbred lines. Plant J. 10:733-736.

Maleck, K., Neuenschwander, U., Cade, R. M., Dietrich, R. A., Dangl, J. L., and Ryals, J. A. 2002. Isolation and characterization of broad-spectrum disease-resistant Arabidopsis mutants. Genetics 160:1661-1671.

Maser, P., Thomine, S., Schroeder, J. I., Ward, J. M., Hirschi, K., Sze, H., Talke, I. N., Amtmann, A., Maathuis, F. J., Sanders, D., Harper, J. F., Tchieu, J., Gribskov, M., Persans, M. W., Salt, D. E., Kim, S. A., and Guerinot, M. L. 2001. Phylogenetic relationships within cation transporter families of Arabidopsis. Plant Physiol. 126:1646-1667.

McDowell, J. M., and Dangl, J. L. 2000. Signal transduction in the plant immune response. Trends Biochem. Sci. 25:79-82.

Michaels, S. D., and Amasino, R. M. 1998. A robust method for detecting single-nucleotide changes as polymorphic markers by PCR. Plant J. 14:381-385.

Muskett, P. R., Kahn, K., Austin, M. J., Moisan, L. J., Sadanandom, A. Shirasu, K., Jones, J. D., and Parker, J. E. 2002. Arabidopsis RAR1 exerts rate-limiting control of $R$ gene-mediated defenses against multiple pathogens. Plant Cell 14:979-992.

Nam, H. G., Giraudat, J., Den Boer, B., Moonan, F., Loos, W., Hauge, B. M., and Goodman, H. M. 1989. Restriction fragment length polymorphism linkage map of Arabidopsis thaliana. Plant Cell 1:699-705.

Neff, M. M., Neff, J. D., Chory, J., and Pepper, A. E. 1998. dCAPS, a simple technique for the genetic analysis of single nucleotide polymorphisms: Experimental applications in Arabidopsis thaliana genetics. Plant J. 14:387-392. 
Penninckx, I. A., Eggermont, K., Terras, F. R., Thomma, B. P., De Samblanx, G. W., Buchala, A., Metraux, J. P., Manners, J. M., and Broekaert, W. F. 1996. Pathogen-induced systemic activation of a plant defensin gene in Arabidopsis follows a salicylic acid-independent pathway. Plant Cell 8:2309-2323.

Pieterse, C. M., and van Loon, L. C. 1999. Salicylic acid-independent plant defence pathways. Trends Plant Sci. 4:52-58.

Rao, M. V., and Davis, K. R. 1999. Ozone-induced cell death occurs via two distinct mechanisms in Arabidopsis: The role of salicylic acid. Plant J. 17:603-614.

Rate, D. N., and Greenberg, J. T. 2001. The Arabidopsis aberrant growth and death2 mutant shows resistance to Pseudomonas syringae and reveals a role for NPR1 in suppressing hypersensitive cell death. Plant J. 27:203-211.

Rate, D. N., Cuenca, J. V., Bowman, G. R., Guttman, D. S., and Greenberg, J. T. 1999. The gain-of-function Arabidopsis acd6 mutant reveals novel regulation and function of the salicylic acid signaling pathway in controlling cell death, defenses, and cell growth. Plant Cell 11:1695-1708.

Richael, C., and Gilchrist, D. 1999. The hypersensitive response: A case of hold or fold. Physiol. Mol. Plant Pathol. 55:5-12.

Richberg, M. H., Aviv, D. H., and Dangl, J. L. 1998. Dead cells do tell tales. Curr. Opin. Plant Biol. 1:480-485.

Ryals, J. A., Neuenschwander, U. H., Willits, M. G., Molina, A., Steiner, H. Y., and Hunt, M. D. 1996. Systemic acquired resistance. Plant Cell 8:1809-1819.

Ryals, J., Weymann, K., Lawton, K., Friedrich, L., Ellis, D., Steiner, H. Y. Johnson, J., Delaney, T. P., Jesse, T., Vos, P., and Uknes, S. 1997. The Arabidopsis NIM1 protein shows homology to the mammalian transcription factor inhibitor I kappa B. Plant Cell 9:425-439.

Schenk, P. M, Kazan, K., Wilson, I., Anderson, J. P., Richmond, T., Somerville, S. C., and Manners, J. M. 2000. Coordinated plant defense responses in Arabidopsis revealed by microarray analysis. Proc. Natl. Acad. Sci. U.S.A. 97:11655-11660.

Schenk, P. M., Kazan, K., Manners, J. M., Anderson, J. P., Simpson, R. S., Wilson, I. W., Somerville, S. C., and Maclean, D. J. 2003. Systemic gene expression in Arabidopsis during an incompatible interaction with Alternaria brassicicola. Plant Physiol. 132:999-1010.

Spoel, S. H., Koornneef, A., Claessens, S. M., Korzelius, J. P., Van Pelt, J. A., Mueller, M. J., Buchala, A. J., Metraux, J. P., Brown, R., Kazan, K., Van Loon, L. C., Dong, X., and Pieterse, C. M. 2003. NPR1 modulates cross-talk between salicylate- and jasmonate-dependent defense pathways through a novel function in the cytosol. Plant Cell 15:760-770.

Sunkar, R., Kaplan, B., Bouche, N., Arazi, T., Dolev, D., Talke, I. N., Maathuis, F. J., Sanders, D., Bouchez, D., and Fromm, H. 2000. Expression of a truncated tobacco NtCBP4 channel in transgenic plants and disruption of the homologous Arabidopsis CNGC1 gene confer $\mathrm{Pb} 2+$ tolerance. Plant J. 24:533-542.

Talke, I. N., Blaudez, D., Maathuis, F. J., and Sanders, D. 2003. CNGCs:
Prime targets of plant cyclic nucleotide signaling? Trends Plant Sci. 8:286-293.

Thomma, B. P., Eggermont, K., Tierens, K. F., and Broekaert, W. F. 1999. Requirement of functional ethylene-insensitive 2 gene for efficient resistance of Arabidopsis to infection by Botrytis cinerea. Plant Physiol. 121:1093-1102.

Ton, J., Van Pelt, J. A., Van Loon, L. C., and Pieterse, C. M. 2002. Differential effectiveness of salicylate-dependent and jasmonate/ethylenedependent induced resistance in Arabidopsis. Mol. Plant-Microbe Interact. 15:27-34.

Tornero, P., Merritt, P., Sadanandom, A., Shirasu, K., Innes, R. W., and Dangl, J. L. 2002. RAR1 and NDR1 contribute quantitatively to disease resistance in Arabidopsis, and their relative contributions are dependent on the $R$ gene assayed. Plant Cell 14:1005-1015.

Trudeau, M. C., and Zagotta, W. N. 2003. Calcium/calmodulin modulation of olfactory and rod cyclic nucleotide-gated ion channels. J. Biol Chem. 278:18705-18708.

Uknes, S., Winter, A., Delaney, T., Vernooij, B., Friedrich, L., Morse, A. Potter, S., Ward, E., and Ryals, J. 1993. Biological induction of systemic acquired-resistance in Arabidopsis. Mol. Plant-Microbe Interact. 6:692-698.

van Wees, S. C., and Glazebrook, J. 2003. Loss of non-host resistance of Arabidopsis NahG to Pseudomonas syringae pv. phaseolicola is due to degradation products of salicylic acid. Plant J. 33:733-742.

van Wees, S. C., de Swart, E. A., van Pelt, J. A., van Loon, L. C., Pieterse, C. M. 2000. Enhancement of induced disease resistance by simultaneous activation of salicylate- and jasmonate-dependent defense pathways in Arabidopsis thaliana. Proc. Natl. Acad. Sci. U.S.A. 18:87118716

Yu, G. L., Katagiri, F., and Ausubel, F. M. 1993. Arabidopsis mutations at the RPS2 locus result in loss of resistance to Pseudomonas syringae strains expressing the avirulence gene avrRpt2. Mol. Plant-Microbe Interact. 6:434-443.

Yu, I. C., Parker, J., and Bent, A. F. 1998. Gene-for-gene disease resistance without the hypersensitive response in Arabidopsis dndl mutant. Proc. Natl. Acad. Sci. U.S.A. 95:7819-7824.

Yu, I., Fengler, K. A., Clough, S. J., and Bent, A. F. 2000. Identification of Arabidopsis mutants exhibiting an altered hypersensitive response in gene-for-gene disease resistance. Mol. Plant-Microbe Interact. 13:277286.

Yu, G. X., Braun, E., and Wise, R. P. 2001. Rds and Rih mediate hypersensitive cell death independent of gene-for-gene resistance to the oat crown rust pathogen Puccinia coronata f. sp. avenae. Mol. PlantMicrobe Interact. 14:1376-1383.

Zagotta, W. N., and Siegelbaum, S. A. 1996. Structure and function of cyclic nucleotide-gated channels. Annu. Rev. Neurosci. 19:235-263.

Zhang, S., and Klessig, D. F. 2001. MAPK cascades in plant defense signaling. Trends Plant Sci. 6:520-527. 